Historic, Archive Document

Do not assume content reflects current scientific knowledge, policies, or practices. 


\section{ORIGINATORS OF}

\section{PRIZE WINNING}
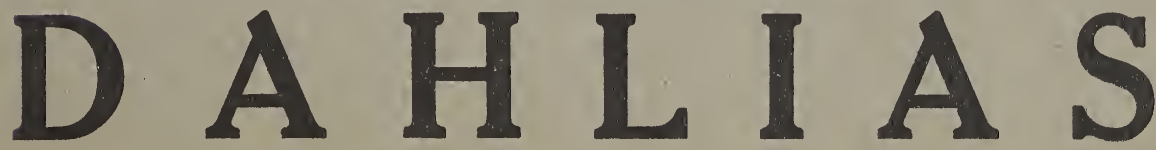

1926

GENUINE

\section{Connecticut Grown}

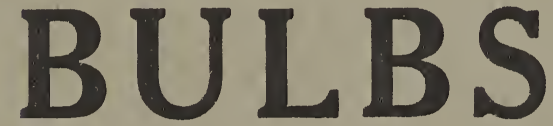

MEACHEN \& SHERMAN

Members of the A. D. S. and D. S. of C.

1661 ELM STREET STRATFORD, - CONN. 
Genuine Connecticut grown bulbs.

Plants half price of tubers and should be entered by February 1st.

\section{INFORMATION}

Order Early: Your orders filled in rotation. Early ordering assures you the varieties you wish

Time of Shipment: Unless you specify shipping date, your order will be shipped about May 1st.

Substitution: We never substitute, but it is well to make a second choice of the best new varieties.

Guarantee: We guarantee all bulbs true to name, and cheerfully replace any that should prove otherwise. Kindly let us know at once.

Stock: We send only field grown divided tubers.

Notice: All orders must be accompanied with cash, money order, or check. No orders sent unless they are paid for.

Invitation: Visitors welcome to our fields at all times. Best blooms during September and October.

\section{ABBREVIATIONS}

Dec. Stands for Decorative. C. Cactus. H. C. Hybrid Cactus. S. Show. Peo. Peony, H. S. Hybrid Show. 


\section{DAHLIAS}

A. C. Lawrence-(H. C.) The color is a very lovely shade of pink. Its large size makes it an exceptionally good flower for exhibition purposes ......................... \$2.00

*Albert Ward-(Peo.) An exceptionally large peony flower, well formed and a free bloomer. Good stems. Color a beautiful shade of light rosolane purple at tips of petals shading darker

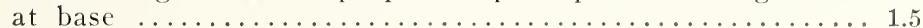

Alicc Long-(D.) A very handsome yellow flower, with serrated petal sometimes tipped white, very attractive flower.......2.00

Ambassador-(C) The largest cactus grown to date. The color is a soft yellow buff, shaded salmon-pink. Flowers are of pleasing form. Size $i-10^{\prime \prime}$ and the best stemed cactus grown 5.00

Arthur Kelsey-(S.) A well formed flower on very good stems, very free bloomer. Good for exhibition. A purplish crimson

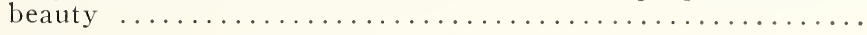

Attraction-(H. C.) One of the best lavender hybrid cactus of

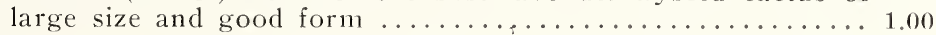

Ballet Girl-A bush often has flowers with several combinations of color, some white, some orange but the majority are orange tipped with white attracting considerable attention... 1.00

Eeachery-(H. S.) A monster hybrid show dahlia. Color is a purple magenta on good stems and fine for exhibition....... 1.00

Ben Wilson-(Dec) This is a very large flower, easily grown 8 inches on good stems. Color is orange red, tipped gold. A

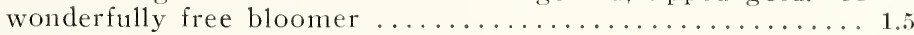

Bonnie Brae-(Dec.) This is the finest cream dahlia shaded pink that we have ever grown. The flowers are immense in size

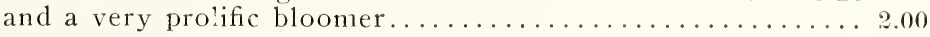

California Superba-(Dec.) This is one of California's varieties. Color light pink The flower is composed of many narrow petals. Stems are stiff, which holds the numerous blossoms upright, retains its center all season ....................50

*Century-(Dec.) A very large lavendar flower of fine form and

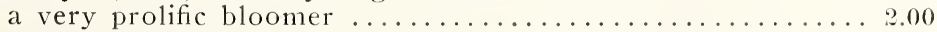

Champagne-(Dec.) This is one of the best California dahlias. This has all the good qualities that is necessary for a good dahlia. It is very lar e and on the best of stems. Colors are warm Autumn shades, varying from buraished copper to a dull golden champagne. This is a dahlia well worth growing 3.50

Charles E. Hughes-(D.) An immense flower, color a lemon yellow, shaded with burnt orange. This is one of the best exhibition flowers we know of, easily grown ten inches on excellent stems. Plants ...................................

*Indicates our own originations. 
*Christine Evers-(Peo.) A very prolific bloomer producing blossoms on extra long straight stems. The face of petals is mallow pink, reverse rhodamine purple shading li hter at tips. A good keeper making it an ideal flower for cutting........ 1.50

Cigarette-This hybrid cactus is a rare beauty. It 1 more vividly colored than the Ballet Girl and is equally as good. Color is a creamy white heavily edged orange. No two flowers exactly alike. Petals are long and narrow and inclined to roll. Flowers are very large on good long stem.................

City of Lawrence-(Dec.) A mammoth deep ye'low on rood stems. One of the deepest dahlias that grows. A free bloomer. If size is what you want this will suit you. It will attract attention in the garden or at an exhibition.......... 5.00

Colleen Bawn (Kernon's 102) - (Dec.) The long, shaggy, slightly twisted petals of this large de^p pink flower faintly tinged with lavendar make up a bloom which must be scen to be ap-

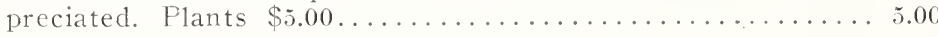

C. P. R.-(D.) An immense flower, color is a buff yellow with magenta shadings. A very handsome flower and one that is well liked. A good grower on good stems, a fine bloomer... 7.50

Daddy Butler-(H. C.) This is a very large hybrid cactus of the truest form for exhibition and a wonderful cut flower, colors are of the American beauty shades or rosy carmine, The petals are twisted and rolled showing a ligliter tint. The stem is perfect and bushes are alway covered with extra large perfect blooms ..............................50

Dignity-(D.) An extra lar e globtilar flower. Color is a light orange yellow, shading to old rose on excellent stems and a

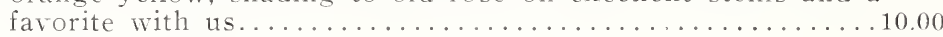

Dr. Marshall A. Howe-(Dec.) A magnificent large pink, edge of petals a shade darker. Flowers are $;-9$ inches in diameter. For beauty and form and color, I hare not seen its equal. This is one of the best exhibition flowers grown. Plants $\$ 5.00 \quad 5.00$

Edward J. Kernon-(H. C.) A very prolific bloomer, color orange red and yellow. Good stems...................... 3.00

E1 Dorado-(Dec.) Size, stem and color of this variety are of the best. It is an immense blossom of vivid gold, deepening in the center. Flowers are held erect on long stiff stems $6 . .50$

El Granada-(H. C.) An immense orange hybrid cactes. The petals twist and interlace, showing at the tips a creamy yellow reverse. This is a fine exhibition flower .................. 10.00

Elizabeth Bostcn-(Peo.) The best and largest peony of its colorings that has so far been produced. Bloons are of deep crimson, shading to old gold at the tips, and will hold ts color the entire season.............................50

*Elsie Daniels-(H. C.) Received a certificate of merit. The color of this wonderful dahlia is a pale orchid shade on the outer petals which are long and shaggy, the center ones are white, making a most wonderful combination of colors. The habits of the plant are all that conld be desired. It grows about four feet tall and the stems are strong enough to hold the extra large flowers erect above the foliage ..............00

Elsie Oliver-(H. C.) A huge deep bloom of regular quilled petals of cream, shading to pink. A flower every one likes.

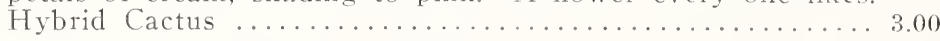


Emma Groot-(D.) A Holland introduction, with very broad

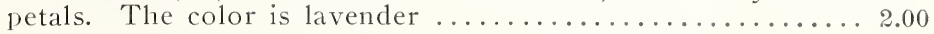

*Empress of India-(Peo.) A very dark velvety maroon borne on extremely long stem way above the foliage. An excellent

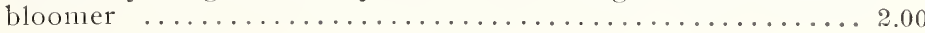

*Enos Pyle-(Dec.) A beautiful golden bronze of the decorative type. Face of the petals, shaded and strealied with jasper and nopal red. Reverse strealed and veined with rosolane purple. Petals are twisted, showing the colors on reverse side. The blooms are very large and are borne on the tips of very long stiff stems. Awarded 87 points at Storrs Trial Gardens ................................ 5.00

Ephrain Gill-(H. C.) This is a very showy flower, color is a light red streaked yellow on the finest of stems........... 1.00

Esther Hunt-(H.C.) The large blooms are composed of long: well rolled petals with serrated tips. The vivid colored flowers of oriental oran e make a most striking bouquet. A very

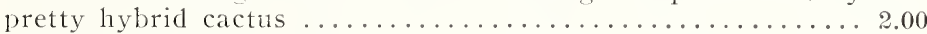

Ethel Hardy-(Peo.) This is one of the finest rose buff colored dahlias grown. It is extra large and on good stems. Fine

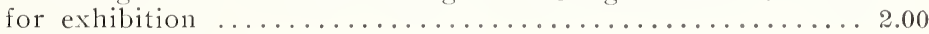

F. M. Burdick-(H. C.) This is a real good hybrid cactus. Fine for exhibition cr cut flower. A good grower and on fine

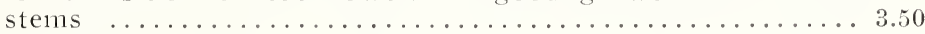

F. T. Fellows-(C) Very large orange scarlet with long narrow

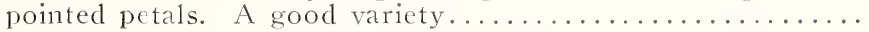

Gee Whiz-(C.) A very large cactus. The color is a soft buff shaded with salmon. Always perfectly double............ 1.50

*GeneralIMcRae-(Dec.) One of our new seedlings. The face of the petals is apricot buff, suffused with rold and the reverse light coral red, making a beautiful combination. The flowers are very large and perfectly formed and are held erect on extra strong, stiff dark colored stems. One of our

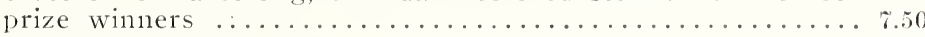

*George C. Meachen-(Dec.) Is a large beautiful formed decorative flower and so deep and full that it is almost round. The face of the peta's is pinard yellow overlaid with a golden sheen. Reverse of outer petals is nopal red, inner petals rose doree strealed with pinard yellow. The petals curl enough to show the colors on reverse side making a most beautiful flower. Stems are straight and strong enou h to hold the hen vy flowers erect above the folia e. The flowers keep well

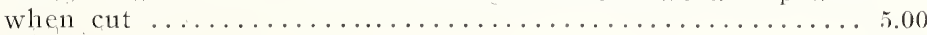

George S. Harvey-(D.) This dahlia is a purplish magenta suffused white, making one of the most beautifui combinations one wculd wish to see. A very large deep flower......... 5.00

Gertrude Brinton-(D.) This is a very large handsome red dahlia. A winner of reds anywhere. Fine large flowers on

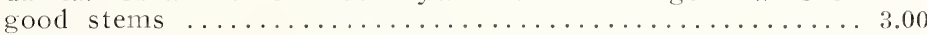

Gladys Bates-(C.) One of the most popular cactus dahlias grown today. Large heavy blooms of incurved petals of tan, with a reverse of rose. Perfect form................. 1.50

Gladys Bedford-(D.) This immense flower is one of the deepest decoratives we have ever rown. Flower; held uprisht on rigid stems and a wonderful bloomer. Color is old rose,

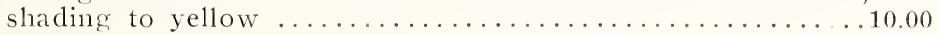


*Governor Trumbull-(D.) A strong growing plant with large full flowers carried on long stems way above the foliage. Color is pink faintly tinged mauve. Stock limited.......... 10.00

Grace Schiott-(D.) A very beautiful flower of a strontion yellow color shaded with salmon on fine stems. A good bloomer 5.00

Grace Sherman-(D.) A very large full flower. The color is a light pink over-laid at the center with a deep golden yellow.

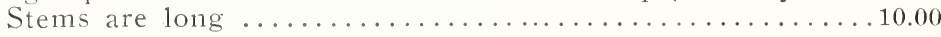

Guardian-(C.) One of the finest cactus grown. It is grown on good strong stems, very free bloomer. Color is deep red... 1.00

Harry Sheldon, Jr.-(D.) A very large pink and white flower, easily grown ten inches and five inches deep, extra good for

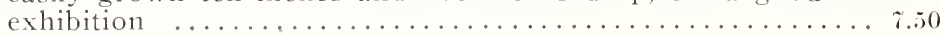

Halvella-(D.) This is a very fine dahlia, color is a beautiful shade of rose pink, flowers are very large on long stiff stems 2.50

Heimweh-(C.) This is a Holland variety. One of the finest cactus we have seen from there. Color is a light cerise on the best of stems ............................... 1.00

Hercules-One of Judge Mareans creations. The flower is a riant in size. Color tangerine and yellow. With us the plants were

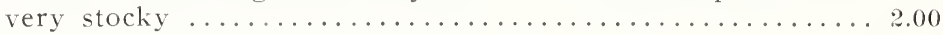

Jersey's Beauty-(Dec.) Very fine true pink. Flowers large and of perfect shape, produced on long, straight, stiff stems. T'ery free bloomer and a splendid keeper. Certificate Amercan

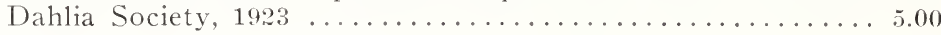

* Joe Jay-(Dec.) We have in this new seedling a coloring that never before has been seen in a dahlia. The face of the petals is a pomegranate purple, the backs Brazil red all over laid with a purplish bronze. Something new .....................

Judge Marean-(Dec.) This dahlia is too well known to describe. One of the best bloomers with large flowers on long stems. It is a glowing salmon pink, yellow and pure gold......... 1.00

Kaliff-(H. C.) A monster hybrid cactus. It is a pure scariet. Flowers often seven inches on long stiff stems. A standard

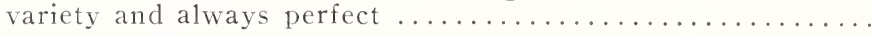

King George-(H.) One of the largest lavendar show dahiias to date. A wonderfully free bloomer, on straight stems and good for exhibition and cut flowers. One of the best...... 1.00

King of Shows-(S.) This is the largest yellow show dahlia to date. It is grown on excellent stems, a very free bloomer... . 1.50

Lady Helen-(H. C.) A strikingly beautiful flower of a cerise color shaded with cream tips all overlaid with silver. Good

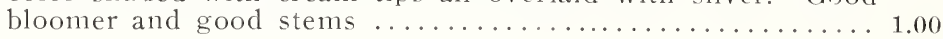

Laura Bedford-(D.) One of the most beautiful yellow and jasper pink dahlias grown. Excellent stems and a very profuse bloomer. Flowers extra large ............... 5.00

La Paloma-(D.) This is a combination of red and yellow with orange and white suffusion. Very attractive flower............

Mabel Thatcher-(D.) Large flowers of pale yellow stiff stems, a good exhibition flower and a profuse bloomer.......... 2.00 
Mariposa-(H. C.) This is one of the best hybrid cactus grown. The bushes are always covered with large flowers. It is a prize winner wherever exhibited. This is one of the best western dahlias that we know of. Color is a delightful shade of violet pink, which is intensified by a violet suffusion. The $b^{1}$ coms are of great depth and substance, borne on extra long

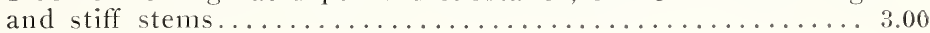

Mariana-(D.) A very beautiful flower of medium size, color is a light orange, shading to burnt orange, on excellent stems, and a fine bloomer .................................. 5.00

* Marion Christine-One of the best decoratives for cut flowers. The color is cadmium tipped with begonia rose. It has long stiff stems and the blooms are beautiful. Thi; is one of the best dahlias of our collection and is recommended for garden

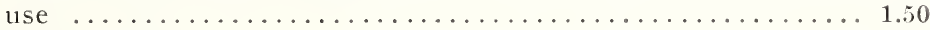

Maicclla Gill-(D.) A very handsome pink dahlia. It has very broad petals, and is a fine bloomer, excellent for cutting

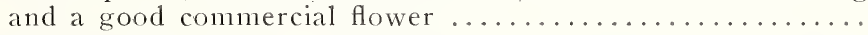

Miss Bridgeport-(D.) A very large white flower of fine formation, excellent stems and a good bloomer. Good for exhibi-

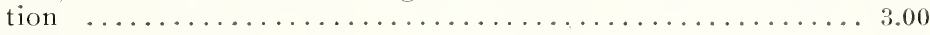

*Miss Martin-(Peon.) This is one of the largest peony flowers rown to date. It is of the perfect form on excellent stems. Color is garnet. A prize winner any place. Stock limited... 5.00

Miss M. E. Dingee-(D.) An enormous flower of color, hard to describe. It is a combination of salmon, orchid and yellow. On the best of stems. It is an excellent dahlia to have .....10.00

Mrs. A. C. Bødford-(D.) One of the most beautiful straw yellow and pink dahlias grown. It is very large and on the best of stems and a good bloomer, fine for exhibition ...........10.00

*Mrs. Charles L. Britten-(H. S.) A new hybrid show. Without disbudding flowers will grow 6-8 in. The outer petals are pink and the center white. A very free bloomer................50

Mrs. Edward Taylor-(D.) Immense flowers of beautiful cerise. This is a dandy on fine stems and has good blooms....... 7.50

Mrs. Edvard Spenccr-(C.) An excellent growing variety. The stems are strong. The flower is a true lavendar cactus shading

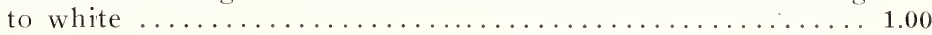

Mrs. Emily Davie-(D.) A very large light rose pink shading to yellow. Flowers are on erect stems, four feet long...... . 5.00

Mrs. E. T. Bedford-(D.) This is one of the most beautiful and largest dahlias grown, color is a deep pink, petals edged with cream. The stems are erect. We consider this a perfect

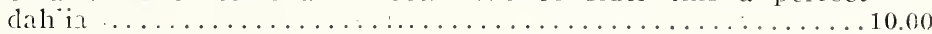

Mrs. Frank Bailey-(H. C.) This certainly is the largest hybrid cactus we know of. Its enormous size and bright canary yellow attracts attention any place. One of the best for exhi-

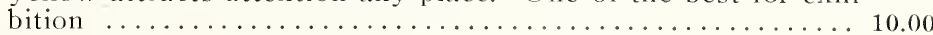

Mrs. F. T. Bedford-(D.) An extra lar e flower of perfect formation, color is a spectrum red, carried on stiff stems, and a fine bloomer ..............................

Mrs. G. S. Floy-(D.) This new seedling is a magenta with each petal streaked white. The flowers are very large on good stems, a very free bloomer and robust grower ............ 00 
Mrs. F. W. Smythe-(D.) A large perfectly formed flower of a scarlet red, carried on good stems and a fine dahlia . . . . . 10.00

*Mrs. George C. Meachen-(D.) A new decorative that is sure to be a winner. The face of the flower is irridescent shadings of picric yellow and corinthian pink with deep rose back. All together it is a very delicate and wonderful color ............10.00

*Mrs. George Sherman-(Peo.) This dahlia produces very tall plants bearing immense blooms on long wiry stems. They are an odd effect in shaded scarlet over a sort of brick red with silver flecks on the outer surface giving an irridescent tex-

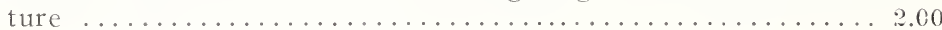

Mrs. George Sherwood-(D.) This is an immense flower borne on excellent stiff stems and is a beautiful golden rose. This

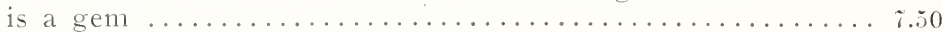

Mrs. Happie Bedford-(H. C.) In this we have a perfect hybrid cactus dahlia. Its enormous size and color will win any where, color is a beautiful canary yellow ....................

Mrs. I. DeVer Warner-(Dec.) One of the best lavender decorative flowers grown. It is enormous in size and has good straight stems. It is a sturdy grower and an exceptionally

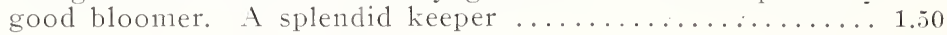

*Mrs. Leo Miller-(Peo.) A flower of unusual color. A deep pink mixed with white. Flowers are large and above all

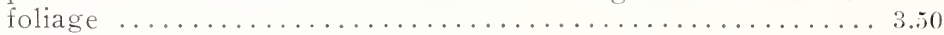

Mrs. J. L. Emerson-(Dec.) Well formed flowers. The ground color a warm shade of red and gold the petals distinctly edged and striped with gold. An ideal flower for garden decorations . . . . . . . . . . . . . . 0

*Mrs. Sally D. Bull-(Peo.) A very large, beautiful flower of exquisite coloring. Face of petals, yellow, reverse rose. Petails curl and twist showing both colors .............. 5.00

Mirs. Seybold-(D.) This is one of the prettiest rose and white dahlias. Excellent for decoration and for cut flowers. A fine

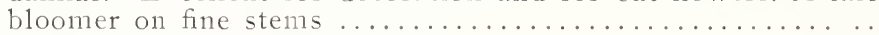

Mrs. Stillman-(Peo.) An exquisite shade of pink. The flower is made up of very long, slin incurving petals that stand up

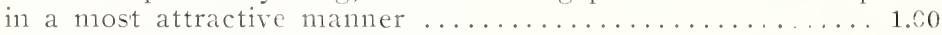

Papillon-(H. C.) This is a very large dahlia. It is a wonderfully improved George Walter, size much larger, steni much better. A beautiful shade of old rose, with golden lights. A wonderful bloomer, stems strong and long that carry the flower well abore the foliage . . . . . . . . . . . . . . 3.00

Paul Michael-Can be grown to majestic size for exhibition if shaded a week before showing. Has been awarded the prize as the largest blossom in shows. Color pure gold.........2.50

Peerless-(D.) A fine clear sulphur blossom of a large size and great depth, on good stiff hard stems. Bushes are always a

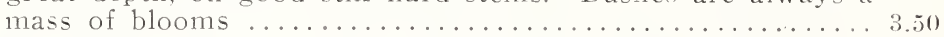

Pollyanna M.-(D.) An extra large buff yellow suffused red. This is an extra large dahlia and a very profuse bloomer. Can

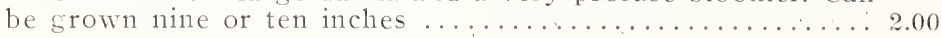

*Pride of Stratford-(D.) Predominating color, cadmium orange shading to light orange yellow at the base of petals' reverse rose doree. Very large flowers, held erect on strong stems.

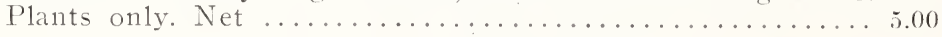


*Radiant-A peony of the most brilliant scarlet, the base and reverse of petals are streaked with picric yellow. It is a good bloomer and the flowers are extra large, and carried on good

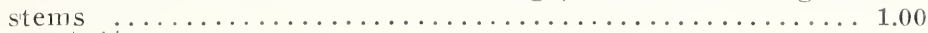

Radio-(Dec.) An enormous red and yellow flower. It might we!l be called a beacon light for it attracts attention from

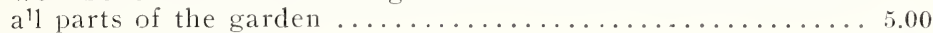

Ralph Blodgett-(Dec.) This is something new and entirely different from other varieties in color which is deep orange with a slight red suffusion and each petal tipped white, very

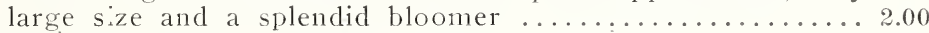

Regent-(C.) One of the best American cactus grown. Its stems and size are very attractive. Color is a beautiful shade of clear nauve pink. Fine for cutting or exhibition ......... 2.00

*Robert H. Sherman-(Dec.) A very large, beautifully formed flower with very: straight stiff stems. Color is pale oran e yellow tipped with apricot. Reverse side of petals spinel pink besutifully veined and shaded. The whole overlaid with golden bronze. A prolific bloomer and wonderful flower. Awarded the certificate of merit ................... 5.50

Robert Scott-(D.) A very beautiful apricot yellow with rose slading and extra large bold flower, excellent stems and a

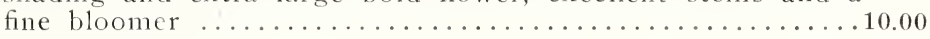

P.osa Nell-(Dec.) A very fine decorative. A pleasing rose pink on long stiff stems, size is enormous, often over 7 inches... 5.50

Posa Bonhcur-(H. C.) Ivory white center shading to a beauti$f_{\text {fll }}$ shell pink; free blooning anl splendid stem. The outer petals prettily twisted and curled, gives a graceful appearance

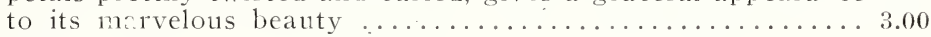

* Sea Shell-(Peo.) Sea shell pink. A prolific bloomer. The very lar flowers carried on long stems are greatly admired 3.00

Shudow's Lavender-(D.) A very large bloem; color is a silvery lavender slightly shading to white.................... 3.00

Sisliyou-(H. C.) This dahlia grows to an enormous size and it produces the largest flowers we have ever seen. It has created a sensation wherever it was grown. Plants are very strong and vigorous. Flowers are held perfectly erect on strons stems, color is pink tinged mauve............. 5.00

*ir Watlins-(D.) This always attracts the attention of visitors in our gardens. It is a very large flower on good stiff stems. Color is an apricot buff, shaded with gold. It is a perfect

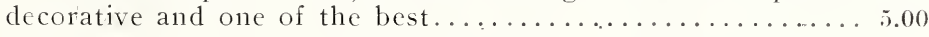

Snowdrift-(Dec.) This giant white bloom deserves its name. A very ftil deep built flower with broad waxy petals. We consider it the best pure white yet on the market............2.00

Susan Coe-(Peo.) A splendid flower of perfect form, large size, carred on long stiff wiry stems, a pleasing sharle of rose pink, passing to a yellow center, suffused salmon as the season advances. Th:s is an excellent dahlia ..................... 30

Susan Lec-(D.) One of largest orange and red dahlias we have ever grown. A prize winner in the lar est flower class

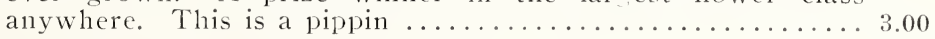


"Sun Glow-(Peo.) Something new. A peony with petals covering the center and little twisted florets between each petal. Color capucine orange, with gold and rose suffusion large

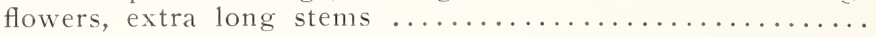

The Emperor-(Dec.) This distinguished dahlia is deserving of a place in every fine collection. It is a strong, healthy grower, producing very large blooms of bright maroon that does not

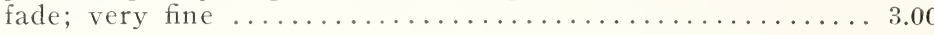

*The General-(Dec.) A deep garnet flower of unusual size with a silvery white reverse, the combination forming a blossom of remarkable beauty and charm. Bulbs ............. 8.50

The Grizzly-(H. C.) A velvety dark, red decorative. The flowers are very large and reflex which makes it very attractive,

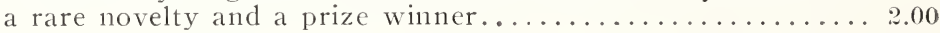

*Uncle Sam-(Peo.) Color, orange buff at base of petals shading to bittersweet pink at tips. All overlaid with a beautiful golden sheen. Center petals mustard yellow streaked with deep pink and beautifully curled and twisted. Reverse side of petals shaded spinel red. Tinis flower is really impossible to describe. It is immense in size measuring 8 to 10 inches without disbudding and is held on stiff stems from 2 to 4 feet long. Every lover of the dahlias should have one. No home or garden complete without "Uncle Sam." Order early ....... 3.00

Violetta-(C.) The color is a petunia violet with little or no shading. The flower is large growing on top of the stem. A very free bloomer ................................... 3.00

Vivian-A very beautiful and a favorite Show Dahlia. The base of the petals is white distinctly edged carmine.........

White Glory-( D.) This is one of the largest and best white flowers grown to date. It is a rugged grower and a profuse bloomer on good strong stems. This is one of the new out-

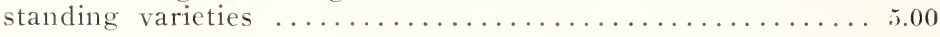

White Star-(D.) This is one of the best white decoratives, we have ever seen from Holland, extra lare on stiff stems and a fine bloomer. This is well worth growing .............. 5.00

W. J. Erwin-(D.) No doubt this is the best lavender purple dahlia ever produced. It surely has size, the best of stems and is a very free bloomer. This is a dahlia everybody likes

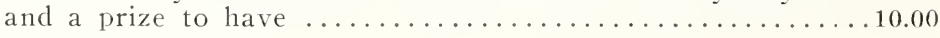

Wm. Bedford-(D.) One of the most beautiful chrome yeliow dahlias with a slight orange shading. On the best of stems

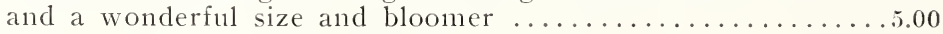

Wonderland-(D.) This is one of the most unique novelties introduced in years. Flowers are of the large exhibition type. face of petals are of a pleasing hue of violet and carmine and a reverse of deep old rose pink, petals are twisted and curled, making a charming combination of this wonderful beaty $\ldots \quad ; .50$

Yellow Prince-(Dec.) Color is a rich golden yellow, flowers are of immense size, a wonderfully good bloomer on stron stem.

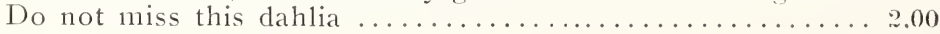

Zeus-In this we have a wonderful novelty, it is nothin 3 to cut ten inch blossom. Color is a rich glowing red, each petal distinctly tipped gold .............................50 


\section{COLLECTION NO. 1}

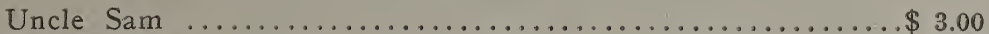

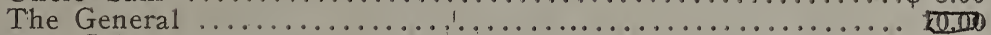

Mrs. Sally D. Bull .....................................

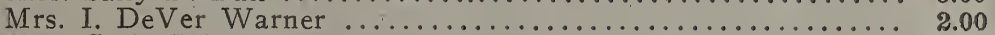

Mrs. C. L. Britten .......................... 5.00

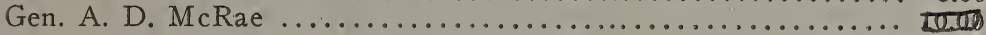

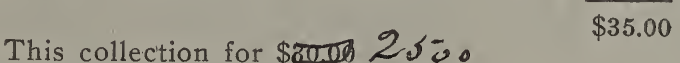

COLLECTION NO. 2

Esther R. Holmes ......................... \$ 2.00

Elsie Daniels .................................. 5.00

Enos Pyle ..................................... 5.00

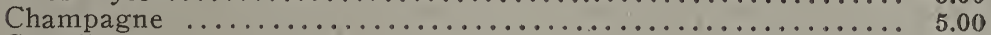

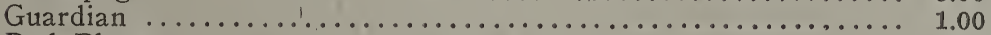

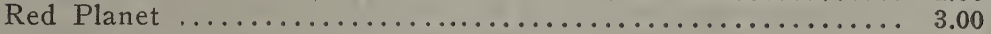

This collection for $\$ 18.00$

COLLECTION No. 3

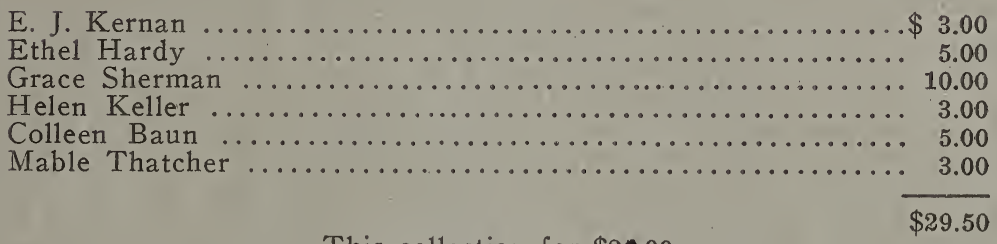

This collection for $\$ 20.00$

$\$ 29.50$

\section{COLLECTION NO. 4}

Our own selection-one dozen- $\$ 5.00$

\section{SPECIAL OFFER OF EXCEPTIONAL VALUE}

Twelve unnamed tubers for $\$ 3$.

All good varieties and no two alike.

On account of this exceeding low price we are unable to tag each one, but we feel sure you will be more than satisfied with the collection. 
